\title{
Awareness about Tuberculosis in people living with HIV/ AIDS: A cross Sectional Institutional Study.
}

Bikal Shrestha ${ }^{1}$, Kapil Pandya ${ }^{1}$, Barun Patel $^{1}$, Rubina Shrestha ${ }^{2}$, Raj Kumar ${ }^{1}$.

${ }^{1}$ Department of Community Medicine, Armed Forces Medical College, Pune. ${ }^{2}$ Dept of Obstetrics \& Gynaecology, Vicente Sotto Memorial Medical Centre,Cebu, Philippines.

\section{ABSTRACT}

Introduction: Worldwide, Tuberculosis (TB) is the most common opportunistic infection affecting HIV seropositive individuals and it remains the most common cause of death in patients with Acquired Immune Deficiency Syndrome. It is estimated that 50 to $60 \%$ of HIV infected people will develop TB in their lifetime. Keeping this in background this study was planned to assess the knowledge, attitudes and practices on TB in HIV positive patients.

Methods: A cross sectional study was carried out in HIV positive individuals attending an ART centre. 100 attendees were selected by systematic random sampling method and interviewed with a pretested, structured questionnaire.

Results: In the study $37.2 \%$ of respondents were not aware about air/droplet as a route of transmission of TB. Only $10 \%$ knew that infective organisms as a common opportunist infection in people with HIV \& AIDS. $78.2 \%$ of the study population felt that the community will treat them differently if they suffer from TB and total of $57.7 \%$ confirmed an attitude of hiding the disease in them.

Conclusions: The overall knowledge about TB in HIV positive individuals is low. Efforts must be made to counsel the patients about TB right in the first counselling session that the patient attends in ART centres so as to prevent spread of TB in the community.

Keywords: TB; HIV; knowledge; awareness.

\section{INTRODUCTION}

Tuberculosis (TB) is an infectious bacterial disease that spreads through the air and most commonly affects the lungs (pulmonary TB). Once infected, a person has about a 10\% lifetime risk of developing the disease and if left untreated, it will kill half of all patients within 5 years and the majority of these within 18 months $^{1}$. For almost 30 years, the epidemics of tuberculosis (TB) and HIV have acted synergistically to produce excess illness and death around the world ${ }^{2}$.
Global estimation of burden of HIV positive incident TB cases is $10,00,000(11,00,000-12,00,000)$. Though only $5 \%$ of TB patients are HIV infected, in absolute terms it ranks 2 nd in the world and accounts for about $10 \%$ of the global burden of HIV associated TB. The estimates of HIV prevalence amongst incident TB cases is estimated to be $3.3 \%(5 \%-7.1 \%)$. While the HIV epidemic in India appears to have peaked, the total number of persons living with HIV/ AIDS remains high, and with time the level of immune deficiency and TB vulnerability may increase $\mathrm{e}^{2-4}$.

Correspondence:

Dr.BikalShrestha

Dept of Community Medicine, Armed Forces Medical College, Wanowarie.

Email: bikal2034@gmail.com 
$\mathrm{TB}$ is the most common opportunistic infection and cause of mortality among people living with HIV (PLHIV), difficult to diagnose and treat owing to challenges related to co-morbidity, pill burden, cotoxicity and drug Interactions ${ }^{3}$, but it is a leading preventable cause of death among people living with HIV. Therefore, it is pertinent to determine the knowledge, attitudes and practices regarding TB in HIV positive population; for the quality of life of patients themselves as well as for curbing the transmission of this important opportunistic infection in the community.Keeping background in mind the study was planned toassess the knowledge, attitude and practicesregarding TB in HIV positive individuals attending ART centre.

\section{METHODS}

A cross sectional study was conducted from Dec 2012 to Feb 2013 in an ART centre of a tertiary care hospital of Western Maharashtra. Sample size was calculated on the basis of awareness level mentioned in previous studies, which came out to be 94 (5\% level of significance and $7.5 \%$ error of margin). Hence 100 patients were planned to be included in the study. Systematic random sampling was used to collect the data. However, the data could be collected and analysed for 98 subjects only. Pre tested and pre validated questionnaire was used as instrument for the study. SPSS version 20 was used for collating and analysis of data.

\section{RESULTS}

It was observed that majority (34.6\%) of patients belonged to age group of 31-40 yrs followed by 20 30 yrs $(25.6 \%)$ and $41-50$ yrs (24.4\%). $7.7 \%$ study subjects were below 20 yrs of age (Table 1). 61.5\% were males and $38.5 \%$ were females in this study. Majority of the respondents $(92.3 \%)$ in the study belonged to Hindu religion while $3.8 \%$ each were Christians and Muslims. Mean age of the respondents was found to be 36.21 years in the range of 16 years to 62 years (Table 1$)$
Table 1.General Demographic Profile of Study Cases $(\mathrm{n}=98)$

\begin{tabular}{|c|l|}
\hline Parameters & Number (Percentage ) \\
\hline Age(Years) & \\
$<20$ & $08(7.7 \%)$ \\
$20-30$ & $25(25.6 \%)$ \\
$31-40$ & $34(34.6 \%)$ \\
$41-50$ & $22(23.1 \%)$ \\
$>50$ & $09(9.0 \%)$ \\
\hline Sex $\quad$ Male & $60(61.5 \%)$ \\
Female & $38(38.5 \%)$ \\
\hline Religion & \\
Hindu & $90(92.4 \%)$ \\
Muslim & $04(3.8 \%)$ \\
Christian & $04(3.8 \%)$ \\
\hline
\end{tabular}

Table 2.Education category in male and female

\begin{tabular}{|l|l|l|}
\hline \multirow{2}{*}{ Education category } & Male & Female \\
\cline { 2 - 3 } & Number (\%) & Number(\%) \\
\hline Illiterate & $09(14.6 \%)$ & $10(26.7 \%)$ \\
\hline Primary & $08(12.5 \%)$ & $04(10.0 \%)$ \\
\hline Middle & $15(25.0 \%)$ & $05(13.3 \%)$ \\
\hline Secondary & $16(27.1 \%)$ & $10(26.7 \%)$ \\
\hline intermediate & $08(12.5 \%)$ & $05(13.3 \%)$ \\
\hline Graduate & $05(8.3 \%)$ & $04(10.0 \%)$ \\
\hline Total & $60(100 \%)$ & $38(100 \%)$ \\
\hline
\end{tabular}

Female were more illiterate (26.7\%) than male (14.6\%). Majority of both male and female were educated up to 10 standards. Very few of them in both male and female were graduated (Table 2).

Table 3. Occupational status in male and female $(\mathrm{n}=98)$

\begin{tabular}{|l|l|c|l|}
\hline Occupation & $\begin{array}{l}\text { Male } \\
(\mathbf{\% )}\end{array}$ & $\begin{array}{l}\text { Female } \\
(\mathbf{\% )}\end{array}$ & $\begin{array}{l}\text { Total } \\
\mathbf{( \% )}\end{array}$ \\
\hline Unemployed & $07(12.5)$ & $01(3.3)$ & $08(7.8)$ \\
\hline Unskilled & $06(10.4)$ & $08(20)$ & $14(13.7)$ \\
\hline semiskilled & $03(4.2)$ & 00 & $03(2.9)$ \\
\hline Skilled & $20(33.3)$ & $20(53.3)$ & $40(39.2)$ \\
\hline Clerical/shop owner & $24(39.6)$ & $09(23.3)$ & $33(32.3)$ \\
\hline Total & $60(100)$ & $38(100)$ & $98(100)$ \\
\hline
\end{tabular}


In the study $39.6 \%$ males had an occupation asclerk / shop keeper while others were skilled worker (33.3\%), unemployed (12.5\%) and unskilled (10\%) respectively. $10 \%$ were unskilled worker. In female $53.3 \%$ were skilled workers, $23.3 \%$ were clerks / shop keeper and $20 \%$ were unskilled worker. In total 39.2\% were skilled workers while $32.3 \%$ were clerical/ shop keeper. Only $13.7 \%$ were skilled workers and $7.8 \%$ were unemployed, out of which $92 \%$ were males (Table 3).

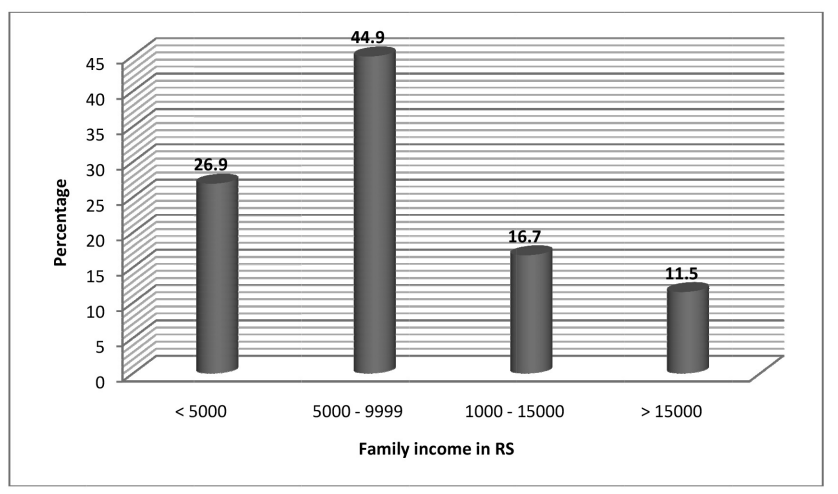

Figure 1.Family Income of Study Cases

In the present study $44.9 \%$ of the respondent's family income was between Rs 5000-1000 per month, 26.9\% percent respondent's monthly family income was less than 5000 thousand per month and $16.7 \%$ of the respondent's income was betweenRs $10000-15000$ per month and only $11.5 \%$ of respondents were earning more than Rs 15000 per month64.1\% belonged to upper lower socio economic class, $30.8 \%$ were from lower middle class and $5.1 \%$ were from lower middle class (Figure 1).

Table 4.Information on TB

\begin{tabular}{|l|l|}
\hline Information on TB & Percentage \\
\hline Medical personal & 44.9 \\
\hline Friends and relative & 16.7 \\
\hline Media ( TV, Newspaper, pamphlets) & 32.4 \\
\hline Others & 6.0 \\
\hline
\end{tabular}

Majority of patients (97.4\%) had heard about Tuberculosis. Among them the main source of information was medical personnel (44.9\%), about one-fifth of the respondents $(24.4 \%)$ had about it from
Media (TV, Newspaper, magazine, posters). $16.7 \%$ of respondents heard from their friends and relatives and $6.4 \%$ from other sources (Table 4 ).

Table 5.Perception regarding symptoms of TB

\begin{tabular}{|l|l|l|}
\hline Symptoms & Numbers & Percentage \\
\hline Cough $>$ 2 weeks & 80 & 82.1 \\
\hline Fever & 25 & 25.6 \\
\hline Bloody sputum & 19 & 19.2 \\
\hline Appetite loss & 20 & 20.5 \\
\hline Sweating & 01 & 1.3 \\
\hline Chest pain & 10 & 10.3 \\
\hline Weakness & 23 & 23.1 \\
\hline Wt Loss & 14 & 14.1 \\
\hline Don't know & 12 & 12.8 \\
\hline
\end{tabular}

Overall awareness about symptoms of Tuberculosis was low in study subjects. Though they had heard about TB, $12.8 \%$ of them were not aware about any symptoms of TB. $82.1 \%$ think that cough more than 2 weeks as a symptom of TB. Only $14.1 \%$ knew weight loss can also be symptoms of TB (Table 5)

Total of $75 \%$ Patients were aware that Tuberculosis is a contagious disease. Regarding mode of transmission of disease, $62.8 \%$ were aware that it spread via coughing, $14.1 \%$ said about sharing food, $6.4 \%$ said it spreads through sexual contacts and $1.3 \%$ said about hand shake.

Total $82 \%$ patients felt that TB is a curable disease and it will be cured by medication. $79.5 \%$ were aware that person suffering from AIDS or infected with HIV are more prone to acquire Tuberculosis infection.

Among study subjects, $24.4 \%$ patients had seen Tuberculosis in their relatives/ friend/neighbours. No one among them had any stigma in visiting their homes. But when asked about social stigma, 57.7\% told that they will hide diseases from others and majority of them $(71.1 \%)$ felt that people will avoid them if they suffer from TB whereas $6.7 \%$ felt that they will lose their friends if they will come to know about their disease. $19 \%$ felt that it's shameful to acquire 
TB in society as they felt that others will avoid them $(66.7 \%)$ and others $(33.3 \%)$ felt they will infect this disease to others. Among study subjects $78.2 \%$ felt that $\mathrm{Tb}$ patients are treated in community differently, among them $73.8 \%$ felt that people avoidTB patients and $23 \%$ felt that other think that these patients will infect others. It was not so good finding when it came to practice of spitting, as $64 \%$ told they spit wherever they feel it convenient and $34 \%$ felt they spit on road.

Table 6.Awareness about prevention of spread $(n=98)$

\begin{tabular}{|l|l|l|}
\hline Prevention of spread of TB & Frequency & Percent \\
\hline $\begin{array}{l}\text { Covering mouth during } \\
\text { coughing/sneezing }\end{array}$ & 49 & 50.0 \\
\hline By washing hands & 01 & 1.2 \\
\hline Taking regular medication & 45 & 46.2 \\
\hline Others & 03 & 2.6 \\
\hline
\end{tabular}

When it comes to awareness about prevention, 50\% felt that covering mouth while sneezing/coughing prevents TB from spreading, $46.2 \%$ felt it can be controlled with help of medication. Another $41 \%$ felt that it can be prevented by vaccination(Table 6 ).

Table 7. Association of Various Socio demographic factors with Knowledge/attitude/ practice regarding Tuberculosis

\begin{tabular}{|l|l|l|l|}
\hline $\begin{array}{l}\text { Socio Demographic } \\
\text { Factors }\end{array}$ & $\begin{array}{l}\text { Knowledge } \\
\text { (Independent } \\
\text { T test, P } \\
\text { value) }\end{array}$ & $\begin{array}{l}\text { Attitude } \\
\text { (Independent } \\
\text { T test, P } \\
\text { value) }\end{array}$ & $\begin{array}{l}\text { Practices } \\
\text { (Chi } \\
\text { Square } \\
\text { Test, P } \\
\text { value) }\end{array}$ \\
\hline Age (<30 \& $>30$ Yrs) & 0.649 & 0.639 & 0.423 \\
\hline Sex ( Male \& Female) & 0.883 & 0.867 & 0.774 \\
\hline $\begin{array}{l}\text { Education ( Illiterate } \\
\text { \& Literates) }\end{array}$ & 0.060 & 0.020 & 0.122 \\
\hline $\begin{array}{l}\text { Occupation (< Skilled } \\
\text { \& S Skilled worker) }\end{array}$ & 0.404 & 0.347 & 0.078 \\
\hline $\begin{array}{l}\text { Income }(<10000 \\
\text { \& }>10000)\end{array}$ & 0.065 & 0.564 & 0.687 \\
\hline $\begin{array}{l}\text { SES (<Upper Lower } \\
\text { \& }>\text { Upper Lower })\end{array}$ & 0.063 & 0.014 & 0.273 \\
\hline
\end{tabular}

Knowledge and attitude were converted into score and compared with socio demographic factors using Independent " $t$ " test. Practice was compared using Chi square test. Only attitude regarding various aspects of Tuberculosis shows significant association with education of the respondents(Table 7).

\section{DISCUSSION}

Mean age was 34 years in a study conducted by Jittimanee SX et al in Thialandwhere maximum patients belong to $31-40$ year's age group ${ }^{5}$ which is in consistent with our findings where the mean age was found to be 36.2 years and maximum subjects belonged to 31-40 years age group. In another study done by Seyoum A et al in eastern Ethiopia showed that the mean age was 28.6 years and maximum subjects belong to $21-40$ years age group ${ }^{6}$.

In Cross sectional study done by Khalil S et al, $61.4 \%$ were male and $38.6 \%$ were female. Majority of the patients $(78.4 \%)$ were Hindu while rest $21.6 \%$ were Muslims .which is in consistent with our finding that $61.5 \%$ is male and $38.5 \%$ were female.In the same study regarding the awareness of symptoms, $75 \%$ were aware about Cough with sputum as the commonest symptom and $19.3 \%$ were not aware of any symptoms of $\mathrm{TB}^{7}$.In our study 82.1 percent were aware about cough for 2 weeks as symptoms of TB where as $12.8 \%$ didn't know any symptoms of TB.

Study conducted in 5 VDCs of Sindhupalchok District in Nepal regarding KAP on tuberculosis in community revealed that more than $40 \%$ of the respondents believed that the infection could be prevented by 'covering mouth and nose while coughing and sneezing ${ }^{8}$. In our study $50 \%$ of the respondents believed that the infection could be prevented by covering the mouth and nose while coughing. In the same study majority of respondents $(81.2 \%)$ perceived that most people in the community feel ashamed after they are infected with TB. In our study $78.2 \%$ said that community will treat them differently.

Although most of them were aware about cough for 2 weeks as a symptom of TB but very few had knowledge of other symptoms like fever, weight loss, loss of appetite as a co-symptom of TB, so therefore IEC should be done regarding knowledge of $\mathrm{TB}$ in ART centre in first visit. Attitude towards the disease is still poor in general community and also stigma in 
MJSBH January-June 2014|Vol 13| Issue 1

society still persist in significant number of population. Measures to reduce stigma in society should be taken. More emphasis should be given in the form of education campaign to reduce stigma in the community.

\section{CONCLUSIONS}

Majority of subjects were aware about Cough as main symptom of TB but a significant number of patients were not aware about any symptom. $2 / 3^{\text {rd }}$ patients were aware about modes of transmission of TB. $82 \%$ had faith in treatment and felt that it will cure the disease. Stigma still persist in the society, about half of study subjects wanted to hide their disease due to social stigma. People still feel shameful to have TB. Half the patients felt that TB can be prevented by vaccination.

\section{REFERENCES}

1. Chin J. Control of communicable diseases manual. 17 th ed. Washington: American Public Health Association; 2000. 624 p.

2. Corbett EL, Marston B, Churchyard GJ, De Cock KM. Tuberculosis in sub-Saharan Africa: opportunities, challenges, and change in the era of antiretroviral treatment. Lancet: 2006; 367: 926-37.http://dx.doi.org/10.1016/S0140-6736(06)683839.

3. Govt. of India. TB India 2012 Revised National Tuberculosis
Control program, Annual status report. Govt of India, Ministry of Family and welfare; New Delhi; 2012. p185.

4. Freudenberg N, Fahs M, Galea S, Greenberg A .The impact of New York City's 1975 fiscal crisis on the tuberculosis, HIV and homicide syndemic. Am J Public Health. 2006; 96: 42434.http://dx.doi.org/10.2105/AJPH.2005.063511.

5. Jittimanee SX, Nateniyom S, Kittikraisak W, Burapat C, Akksilp S. Social Stigma and Knowledge of Tuberculosis and HIV among Patients with Both Diseases in Thailand. PLoS ONE. 2009; 4(7): e6360. doi:10.1371journal.pone.0006360.

6. Seyoum A, Legesse M. Knowledge of tuberculosis (TB) and human immunodeficiency virus (HIV) and perception about provider initiated HIV testing and counselling among TB patients attending health facilities in Harar town, Eastern Ethiopia. Seyoum and Legesse BMC Public Health. 2013; 13:124.http://dx.doi.org/10.1186/1471-2458-13-124.

7. Khalil S, Ahmad E, Khan Z, Perwin N. A study of knowledge and awareness regarding pulmonary tuberculosis in patients under treatment for tuberculosis in a rural area of Aligarh UP. Indian Journal of Community Health.2011; 23 (2):93-5.

8. Govt. of Nepal. Knowledge Attitude and Practices Study on Tuberculosis among Community People. Report of Sindhupalchok District. Government of Nepal Ministry of Health and Population National Tuberculosis Centre 2009. 